\title{
„Nekem ez most jó a kislány végett” Nói tapasztalatok a közfoglalkoztatási programról
}

\author{
Fekete Dorottya \\ fekete_dorottya@alumni.ceu.edu \\ https://doi.org/10.51624/SzocSzemle.2020.3.4 \\ Beérkezés: 2020. 01. 29. \\ Átdolgozott változat beérkezése: 2020. 05. 28. \\ Elfogadás: 20२०. 06. १८.
}

\begin{abstract}
Összefoglaló: A tanulmány a közfoglalkoztatásban való részvétel okait és a résztvevők által érzékelt előnyöket és hátrányokat vizsgálja, valamint azonosítja a különbségeket a női és a férfi közfoglalkoztatottak tapasztalatai között, továbbá meghatározza azokat az okokat, amiért a közfoglalkoztatási program vonzóbb lehet a nők számára. A tanulmány megírásához 15 közfoglalkoztatottal és három munkafelügyelővel készítettem interjút Komárom-Esztergom és Pest megyében. A női résztvevők a programot egyfajta stratégiai eszközként kezelik, amelynek segítségével összeegyeztethetik a munkát a magánélettel egy olyan kontextusban, ahol a munkaerôpiacra a kiszámíthatatlan munkaidő és a rugalmatlan munkakörülmények jellemzőek. Ennek a stratégiának köszönhetően a nők továbbra is képesek a munka és a magánélet kettős terhét viselni, így a közfoglalkoztatás ahelyett, hogy orvosolná, erősíti a munkaerőpiaci diszkriminációt, elősegíti a kizsákmányolást és fenntartja az ideális munkavállaló normájának társadalmi nemek mentén meghatározott jellegét. A közmunkában a nők aránya egyre jobban növekszik, ami arra utal, hogy a közfoglalkoztatás egy olyan új típusú női munka, amely tolerálja a nők gondoskodási feladatait csakúgy, mint a legtöbb elnőiesedett munka a másodlagos munkaerôpiacon. A női résztvevők úgy érezték, hogy emocionális és szociális előnyben részesülnek annak ellenére, hogy a közmunka egy bizonytalan jellegü foglalkoztatás. Lehetőségeik az elsődleges munkaerőpiacon annyira szúkek voltak, hogy a közfoglalkoztatás számukra felértékelődött. Mivel a munka a férfiak esetében szorosan kötődik a családfenntartó szerephez, valamint a szakmából nyert identitáshoz, a közmunka számukra csak anyagi célt szolgál, és nem kötődik hozzá különösebb jelentés vagy személyes kiteljesülés.
\end{abstract}

Kulcsszavak: aktív foglalkoztatáspolitikai eszközök, workfare, nemek, foglalkoztatás, munkaerőpiaci egyenlötlenség

\section{Bevezetés}

A közfoglalkoztatási rendszert 2011-ben egységesítették Magyarországon. Az új rendszerben a közfoglalkoztatottak - vagy a köznyelvben közmunkások ${ }^{1}$ - egy speciális jogviszonyban vesznek részt a programban, amely lehetővé teszi, hogy a ga-

1 A közfoglalkoztatás a hivatalos elnevezése egy olyan aktív foglalkoztatáspolitikai eszköznek, amely munkajövedelemhez juttatja a foglalkoztatást helyettesítő támogatásban részesülőket. A köznyelv sok esetben közmunkaként utal erre a speciális foglalkoztatási formára (Közfoglalkoztatás 2020). Az interjúpartnerek is a közmunka szót használták, ezért a tanulmány a közfoglalkoztatás, illetve a közmunka fogalmát szinonimaként, felcserélve használja. 
rantált bérminimumnál alacsonyabb, kormányrendeleteken keresztül meghatározott fizetést kapjanak a résztvevők (Bördős 2014: 69). A közfoglalkoztatás célja, hogy visszavezesse a résztvevőket a munkaerőpiacra továbbképzés és munkaszocializáció segítségével (Közfoglalkoztatás 2019). A résztvevők azonban gyakran beragadnak a programba, ezért a közfoglalkoztatási rendszert sokszor hatástalannak ítélik meg a munkaerőpiacra való integrációban. Ezenfelül a programban való részvétel feltételei több esetben is csökkentik az egyén szabadságát, illetve erősítik az egyenlőtlen hatalmi viszonyokat, lehetőséget adnak a résztvevők kizsákmányolására.

Ez a tanulmány a közfoglalkoztatás nemek közötti különbségeinek és elnőiesedésének okait vizsgálja a következő kérdéseken keresztül: Mik a lehetséges okai annak, hogy a nők nagyobb arányban ragadnak be a közfoglalkoztatásba, mint a férfiak? Hogyan ítélik meg a nők a közfoglalkoztatás előnyeit, illetve hátrányait? Ez eltér-e attól, amit a férfiak gondolnak? Ajánl-e valamit a közmunka a nők számára, ami egy vonzóbb foglalkoztatási formává teszi azt? Ezeknek a kérdéseknek a megválaszolásával a kutatás célja, hogy a közfoglalkoztatottak egyéni narrációjából vizsgálja meg a programot, illetve a nemek közötti eltérést elemezze.

2016-ban a közfoglalkoztatottak száma rekordmagas volt, több mint 220 ezer fő, vagyis a munkavállalók 5 százaléka dolgozott közmunkásként. Ugyanebben az évben a kormány különböző munkaerőpiaci intézkedésekkel próbálta csökkenteni a közfoglalkoztatottak számát. Részben ennek, részben pedig a közfoglalkoztatás szerkezetének átalakításának hatására ${ }^{2}$ a résztvevők nemek szerinti aránya felcserélődött. 2016-ban a női közmunkások száma először haladta meg a férfiakét. Mint az 1. ábra is mutatja, ez a tendencia azóta is folytatódik annak ellenére, hogy a közfoglalkoztatottak száma folyamatosan csökken, 2020 februárjában például kevesebb mint 100 ezer embert foglalkoztattak (Közfoglalkoztatás 2020). Ez azt jelenti, hogy a nők nagyobb számban ragadnak be a programba. Míg a rendszer kiépítése idején az inaktív személyek bevonása volt a legnagyobb kihívás, 2016-tól a beragadás jelentette a legnagyobb gondot (Belügyminisztérium 2017: 10). 2017-ben a közfoglalkoztatottak több mint 60 százaléka nevezhető beragadónak, és ez a szám az 50 év felettiek esetében 70 százalék fölé emelkedett (Busch-Lakatos 2017: 195).

2 Az 1139/2017. (III. 20.) határozat alapján a kormány folyamatosan csökkenteni kívánta a közfoglalkoztatottak számát, 2020-ig 150 ezer före (Közfoglalkoztatás 2017). Ennek megfelelően 2020 januárjára 100 ezer alá csökkent a közfoglalkoztatottak száma (Közfoglalkoztatás 2020). Ezenfelül a közfoglalkoztatási rendszer átalakításakor az országos közfoglalkoztatási programokat, amelyek magasabb arányban foglalkoztattak férfiakat, leépítették (Belügyminisztérium 2017: 29, 2019: 3). 


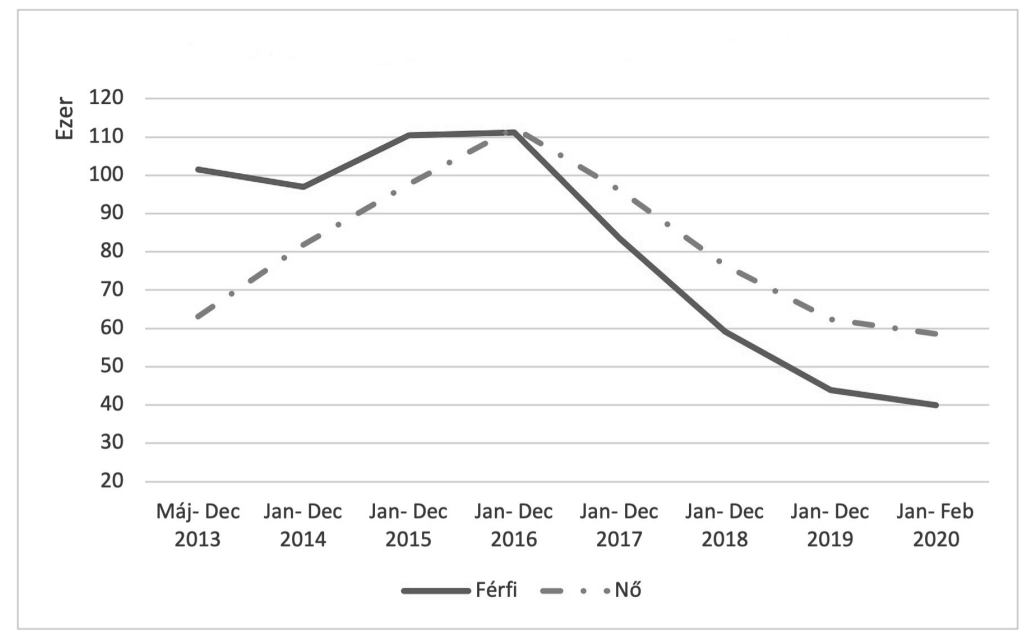

Forrás: saját szerkesztés a Belügyminisztérium havi adatai szerint; Közfoglalkoztatás 2020

Bár ez a tanulmány a nemek közötti különbségekre fókuszál, fontos kitérni a regionális különbségekre a közfoglalkoztatási programban. Kelet- és Északkelet-Magyarországon a legmagasabb a közfoglalkoztatottak aránya ${ }^{3}$. 2016-ban nyolc megyében volt tíz százalék körül a közfoglalkoztatottak száma, Szabolcs-Szatmár-Bereg megyében volt ez a legmagasabb, 18 százalék (Belügyminisztérium 2017: 8). Ezekben a régiókban a roma lakosság száma magasabb, mint az országos átlag, több mint 30 százalékos. Pest és Komárom-Esztergom megyében, ahol az interjúk készültek, ez a szám, 4,3 és 1,8 százalék volt (KSH 2011).

A tanulmány megírásához 18 interjú szolgál alapul, amelyek Komárom-Esztergom és Pest megye két kiválasztott településén készültek, ahol kimondottan alacsony, 0,5 százalékos a közfoglalkoztatottak aránya az interjúk idején (Közfoglalkoztatás 2020). Az interjúpartnerek között tizenöt közmunkás és három munkafelügyelő volt. A közmunkások közül tizenegy nő, négy pedig férfi. A résztvevők különböző munkakörökben dolgoztak: közterület-fenntartás, adminisztratív munka a helyi önkormányzatnál és tanodában, illetve sütödében való segédkezés egy jótékonysági szervezetnél.

A következő részben a tanulmány áttekinti azokat az elméleteket, amelyek a közfoglalkoztatás és a workfare kapcsolatáról, illetve a munka-magánélet összeegyeztetéséről szólnak. Ezután következik a módszertan rövid bemutatása és a kutatási eredmények értelmezése. Végül a tanulmány az eredményekból levonható kö-

3 A közfoglalkoztatottak 15-74 évesekre számított százalékaránya a foglalkoztatottakon belül. 
vetkeztetésekről és a közfoglalkoztatási rendszer munkaerőpiaci hatásáról értekezik.

\section{Szakirodalmi háttér}

\section{A workfare manifesztációja Magyarországon}

A jóléti ellátások közcélú munkához való kötése, vagyis a workfare-rendszer egy olyan aktivációs beavatkozás, amelynek célja, hogy visszavezesse a munkanélkülieket és más, hátrányos helyzetű csoportokat az elsődleges munkaerőpiacra (Kálmán 2014: 42). A rendszer amerikai eredetű, ahol az 1980-as években vezették be azokat a programokat, amelyek a segély folyósítását munkához kötötték (Kálmán 2014: 44; Keller et al. 2016: 13; Kildal 2001: 3). Az 1990-es évektől, valamint a 2008-as gazdasági és pénzügyi válság kitörése óta egyre több fejlett ország távolodott el a feltétel nélküli segélyezéstől, illetve egyre nagyobb hangsúlyt fektetnek a különböző feltételekhez és kötelezettségekhez kötött jóléti ellátásokra (Kálmán 2014: 44; Lødemel - Trickey 2001: xi).

Ennek az aktív programnak a központi logikája, hogy a passzív ellátások csökkentik a munkavállalási hajlandóságot és fenntartják a jóléti ellátásoktól való függést (Kálmán 2014: 48). A különböző szankciók és feltételek a munkavállalásra ösztökélnek, mert szűrőként múködnek, vagyis a leginkább rászorulók kerülnek a programba, és/vagy elrettentő hatással bírnak, vagyis a résztvevők minél előbb ki akarnak lépni a segélyezésből (Besley - Coate 1992: 249). A nemzetközi kutatások leggyakrabban azért kritizálják ezeket a programokat, mert nem elég célzottak, szisztematikusak, és éppen a legjobban rászorulók nem jutnak segélyekhez (Acosta - Olfindo 2016: 9; Kluve et al. 2002: 413). Ezenfelül a résztvevők sokszor nem ugyanolyan mértékben részesülnek a program előnyeiből (Martin - Grubb 2001: 25; Messing 2013: 7). Az Egyesült Királyság workfare-programjaiban például gyakori az úgynevezett „creaming”- és „parking”-effektus, miszerint a leginkább munkaképesnek ítélt embereket kiterelik a programból, míg azokat, akik kevésbé tűnnek munkaképesnek, parkoltatják, vagyis ők beragadnak a programba. Wacquant (2009: 14-15) szerint a workfare rendszere lehetőséget ad a szegények büntetésére, illetve viselkedésük szabályozására. Ezenfelül a rendszer hangsúlyozza az egyén felelősségét, és nemcsak csökkenti az állam szerepét a perifériára szorult egyének segítésében, de ki is alakít egy képet a megfelelő munkavállalóról (Wacquant 2009: 8, 101). Így a workfare rendszere amellett, hogy egy eszköz a szegények ellenőrzésére, értéktelennek ítéli meg és nem ismeri el a nem fizetett munkát, amelynek nagy részét nők végzik. Ezáltal a rendszer hozzájárul a nemek közötti különbségek mélyítéséhez, figyelmen kívül hagyja a nők által végzett munkát, és nem számol azzal, hogy a nők gyakrabban szorulnak segélyekre gondoskodási feladataik miatt. Ennek értelmében 
a workfare egy büntető rendszer az olyan kiszolgáltatott csoportok számára, mint például a nők vagy a kisebbségek.

A magyar közfoglalkoztatási programban is gyakori volt a beragadás 2012 és 2014 között; a résztvevőknek kevesebb mint 20 százaléka tudott elhelyezkedni az elsődleges munkaerőpiacon (Albert 2015: 4; Cseres - Gergely - Molnár 2014: 147; Kálmán 2014: 49). Ezenfelül a közmunkaprogramban foglalkoztatottak határozott idejú szerződéssel és minimálbér alatti kereslettel rendelkeznek (Bördős 2014: 69_ 70). Így a program nemcsak abban volt sikertelen, hogy visszavezesse a munkaerőpiacra a résztvevőket, hanem az alacsony bérezéssel a kizsákmányolást és a gazdasági függést is elősegítette egy bizonytalan foglalkoztatási formát létrehozásával. MacDonald (2009: 168) szerint a prekárius munka a munkaszerződés időtartama szerint azonosítható. A határozott idejű, kisebb állásbiztonságot jelentő munkák prekáriusnak tekinthetőek. A prekárius munkához azonban hozzátartozik a megnövekedett kiszolgáltatottság a különböző juttatások elvonása miatt, mint például a betegszabadság, a nyugdíj vagy a fizetett szabadság (Cazes - de Laiglesia 2015: 147). A kutatás alapján a közmunka egy prekárius munka, hiszen a határozott idejü szerződések váratlanul és azonnali hatállyal véget érhetnek. Habár a résztvevők részesülnek társadalombiztosításban, és fizetnek nyugdíjjárulékot, kevesebb szabadsággal rendelkeznek, illetve a munkatörvények nem vonatkoznak rájuk, hiszen a közmunka egy sajátos jogviszonnyal rendelkezik (Bördős 2014: 69). Tehát a munkaerőpiaci diszkrimináció és szegmentáció a közmunkaprogramon keresztül kerül intézményesítésre (Tardos 2015: 36). Ez erősíti a nemek közötti különbségeket, hiszen 2016 óta a nők nagyobb számban vesznek részt a közfoglalkoztatásban, mint a férfiak. A közfoglalkoztatásban dolgozó nők 45 százaléka 15 évesnél fiatalabb gyermeket vagy gyermekeket nevel. Tehát a közmunka vonzó a gyermeket nevelő nők számára, legfőképp azért, mert a lakóhelyükön biztosít foglalkoztatást (Busch - Lakatos 2017: 196). A kutatási eredményeim ezt az állítást alátámasztják, illetve bővítik.

\section{Munka-magánélet konfliktusát enyhítő szereplők és intézkedések}

A munka-magánélet konfliktusának feloldását kapcsolati szinten két szereplő befolyásolja: a támogatási hálók és maguk a párok; míg strukturális szinten két másik: az állam és a munkahely (Guerreiro - Pereira 2007: 193; Perrons et al. 2007: 133).

Támogatási hálók alatt olyan fizetett vagy nem fizetett segítséget értünk, ami a gondoskodási feladatok megkönnyítését célozza, ilyen például egy babysitter vagy a nagymama tevékenysége (Guerreiro-Pereira 2007: 193; Utrata 2011: 617). Ezek az opciók azonban az alacsonyabb jövedelmű családban élő nők számára sokszor nem elérhetőek (Crompton et al. 2010: 10). A párok munkamegosztását nagymértékben befolyásolják a nemi szerepekhez fűződő attitűdök. A nemi szerepek szerint három különböző kombinációja lehet a munka és a család összeegyeztetésének: az egalitá- 
rius modell (két kereső, két gondoskodó), az átmeneti modell (egy és fél kereső) és a tradicionális modell (férfi kereső, női gondoskodó) (Hochschild - Machung 1989: 75; Wall 2007: 87).

Strukturális szinten az állam különböző intézkedésekkel segítheti a családokat, mint például a szülői szabadsággal vagy megfelelő számú és megfizethető gyermekgondozó intézmények létrehozásával (Crompton et al. 2007: 6; Williams 2000: 85). Az intézkedések sikere azonban gyakran függ a munkahelytől. Többek szerint elengedhetetlen a szervezeti kultúra megváltoztatása a munka és a magánélet összeegyeztetéséhez (Acker 1990; Lewis 1996: 6), amelyet az állam családbarát politikája sok esetben nem kérdőjelez meg (Kelly et al. 2010: 282; Lewis 2001). Acker (1990) szerint a különböző szervezetek fenntartják a nemek közötti egyenlőtlenségeket, mivel múködésük a nemek közötti munkamegosztáson alapul. Míg a férfiak „természetük révén" olyan munkák elvégzésére alkalmasak, amelyekhez nagyobb felelősségvállalás szükséges, és amelyek több döntéshozatallal járnak, addig a nőknek olyan munka „való”, ahol kisebb a kötelezettségvállalás (Acker 1990: 149). A munkahelyek azokat a dolgozókat preferálják, akiknek nincsen munkahelyen kívüli kötelességük, vagyis akik elsőbbséget tudnak biztosítani a munkának a családdal szemben (Acker 1990; Brumley 2014: 799; Lewis 2001: 21; Williams et al. 2012: 549). Így az ideális munkavállaló normája szorosan összefonódik a tradicionális nemi szerepekkel, és a nők otthon végzett láthatatlan munkáján alapul (Kelly et al. 2010: 294). Ezért a gondoskodási feladatok és az anyaság erősen ellentétben állnak az ideális munkavállaló képével, és negatív feltételezéseket generálnak az anyák elkötelezettségéről, illetve szakértelméről (Correll et al. 2007: 1301; Williams 2010: 92).

A nemek közötti egyenlőtlenség sok esetben a munkavégzési tevékenységben és a munka megtervezésében is megnyilvánul (Williams 2000: 65). A munkáltatói gyakorlatok és a foglalkoztatási politika, mint például a munkaidőre vagy a betegszabadságra vonatkozó szabályozások, olyan elvárásokat kreálnak, amelyek a férfiaknak kedveznek (Brumley 2014: 801). A napközi gyermekfelügyelet elintézése kihívást jelent az olyan munkavállalóknak, akik váltott munkarendű vagy több műszakos munkát végeznek (Williams 2000: 80, 2010: 46). Ennek a problémának a megoldása a nőkre hárul. A megoldást sok esetben a másodlagos munkaerőpiacon, az úgynevezett rózsaszíngalléros (pink-collar) munkákban találják, ahol a fizetések alacsonyabbak, és a női dolgozók felülreprezentáltak a férfiakhoz képest (Williams 2000: 82). Ez a megoldás hozzájárul a munkaerőpiac szegmentálásához (Gill-Greene 2015). Más esetekben a rugalmas munkaidőt említik megoldásként, az azonban nem érhető el az olyan, alacsony végzettséggel végezhető munkahelyeken, ahol a munkaidőt szigorúan ellenőrzik, és a fizetést a ledolgozott órák határozzák meg (Perrons et al. 2007: 147). Ezenfelül a rugalmas munkaidő fenntartja a nők elsődleges szerepét mint anya és feleség, mivel arra nyújt megoldást, hogy a nők továbbra is elvégezzék az otthoni munkát, ahelyett hogy a nemek közötti munkamegosztáson változtatna (Mandel - Semyonov 2006: 1911). 
Összességében tehát a nők részvétele a közfoglalkoztatási programban egy olyan kontextusban történik, ahol a munkahelyi gyakorlatokat az ideális munkavállaló normája irányítja. Az elsődleges munkaerőpiac így egy büntető rendszert múködtet, amely kiszorítja onnan a gondoskodási feladattal rendelkező nőket. Ezáltal a közfoglalkoztatás egy újfajta rózsaszíngalléros munkává válik, ahol a nők családi kötelességeit tolerálják, de egyben fenntartják az alárendelt helyzetüket a munkaerőpiacon. Így a közfoglalkoztatási program hozzájárul a munkaerőpiac szegmentálásához, és a másodlagos munkaerőpiac tulajdonságait, annak bizonytalanságát, illetve alacsony bérét másolja le és reprodukálja.

\section{Módszertan és az interjúpartnerek demográfiai adatai}

A tanulmány 18 félig strukturált interjú alapján készült, amelyeket 2019 áprilisában készítettem Komárom-Esztergom és Pest megyében. Az interjúk átlagosan 45 perc hosszúak voltak, és az interjúpartnereken kívül nem tartózkodott senki más a közelben, kivéve egy esetben, ahol a résztvevő az unokájára vigyázott. Azért, hogy az anonimitást biztosítsam, a pontos települések nincsenek megnevezve, az interjúpartnerek pedig álnevekkel jelennek meg a tanulmányban. A 18 interjúpartner közül 15 dolgozott közfoglalkoztatottként, és hárman munkafelügyelők voltak. A kiindulási pontok mindegyik esetben a munkafelügyelők voltak, akik közül kettő nő és egy férfi volt. Egy nő és egy férfi a helyi nonprofit városüzemeltető cégnél dolgozott, míg egy nő szociális munkásként egy karitatív szervezetben. Ők kötöttek össze a közmunkásokkal, illetve engedélyezték, hogy munkaidőben beszéljünk. Ez hatással lehetett az interjúra való hajlandóságra, illetve a résztvevők saját feladatainak, munkakörének megítélésére.

A közfoglalkoztatottak többsége, összesen tízen roma származásúnak vallották magukat, és a nők aránya magasabb volt, mint a férfiaké. Tizenegy nővel és négy férfival készítettem interjút. A nők átlagéletkora 45 év volt, de két jól kivehető korcsoportba különültek el: hatan voltak átlagosan 35 évesek és öten 55 év körül. A férfiak életkor szerint szintén két csoportra voltak oszthatóak: hárman 57 év körül voltak, illetve volt egy 22 éves férfi, ő volt a legfiatalabb, akivel beszéltem. Hét résztvevőnek nyolc általános volt a legmagasabb végzettsége. A férfiak közül mindenkinek volt szakmája, illetve két nőnek, akik közül az egyik sose tudott a szakmájában (virágkötő) elhelyezkedni. Két nő érettségivel rendelkezett. A résztvevők közül nyolcan a szabadban dolgoztak, közterület-fenntartás munkakörben, heten pedig zárt térben: öten egy jótékonysági szervezet sütödéjében, ketten pedig a helyi önkormányzatnál. A zárt térben dolgozók mind nők voltak. A résztvevők kétharmada 54 ezer forintot keresett az interjú ideje alatt. Négyen a családi adókedvezmény miatt ennél többet, 70-80 ezer forintot kerestek. A résztvevők közül egy roma nő már az interjú idejében elhelyezkedett a munkaerőpiacon, ő volt az egyik résztvevő, aki 
érettségivel rendelkezett, és az egyetlen, aki kulturális vagy kiemelt közfoglalkoztatottként dolgozott, ezáltal 71 ezer forintot keresett havonta.

A résztvevők közfoglalkoztatási programban eltöltött ideje változó volt. Voltak, akik pár hónapja dolgoztak közmunkásként, és volt, aki már 10 éve. A legtöbben hat hónapja voltak alkalmazva. Többen mondták, hogy a közterület-fenntartással foglalkozók körében előfordult, hogy váratlanul elküldték őket. Volt, akiknek azért szakadt meg a közfoglalkoztatotti státusza, mert egy ideig más fizetett vagy nem fizetett munkát végezett, majd újra jelentkezett a közfoglalkoztatási programba. Két résztvevőt egy 22 éves, fogyatékkal élő férfit és egy 33 éves nőt - kivéve mindenki évekig dolgozott a munkaerőpiacon a közmunkát megelőzően. A legtöbben az informális szektorban dolgoztak. Többen dolgoztak bejelentve üzemekben, például csomagolóüzemben vagy csirkefeldolgozóban, de vagy az egészségi állapotuk vagy a családi kötelezettségeik miatt eljöttek. Az 50 év felettiek körében négyen voltak olyanok, akik azután kerültek a közfoglalkoztatási programba, hogy a vállalat, ahol dolgoztak, tönkrement.

\section{Kutatási eredmények}

Az egyéni narrációk alapján elmondható, hogy az alacsony végzetséggel és gondoskodási feladatokkal rendelkező nők számára annyira kevés lehetőséget nyújt az elsődleges munkaerőpiac, hogy a közfoglalkoztatás egy vonzó munkává válik. Az interjúpartnerek kiemelték a közfoglalkoztatás kiszámítható munkarendjét, közeli elhelyezkedését és kedvezőbb feltételeit (például szabadság, gyed). Ezenfelül az interjúpartnerek azt érzékeltették, hogy a közfoglalkoztatás lehetőséget ad a nőiesnek gondolt közösségi és emocionális szükségletek kielégítésére.

A közmunka által azonban a nők kiszorulnak az elsődleges munkaerőpiacról, és egy másodlagos piacnak lesznek a részesei. Részben azért, mert családi és háztartásbeli kötelezettségük miatt nem felelnek meg a társadalmi nemek mentén meghatározott ideális munkavállaló normájának (Acker 1990). Ezt a strukturális problémát a közfoglalkoztatási rendszer fenntartja. Tehát ebben a kontextusban a közmunka egy olyan munkalehetőséget jelent, amely tolerálja a nők otthoni feladatait, és nem kérdőjelezi meg a rugalmatlan munkaidőt. Ezáltal hozzájárul a férfiak hosszú munkaidejéhez is. Az interjúk azt mutatják, hogy a közfoglalkoztatás egy olyan stratégia, amely lehetővé teszi a munka és a magánélet közötti „egyensúly” megteremtését, vagy másképpen: lehetővé teszi, hogy a nők egyedül viseljék a munka és az otthoni feladatok kettős terhét. Tehát a közfoglalkoztatás - csakúgy, mint más elnőiesedett foglalkozási formák - nem nyújt valódi megoldást a munka és a magánélet összeegyeztetésére.

Ebben az alfejezetben először bemutatom, hogy a nemi szerepek hogyan korlátozzák a nők munkalehetőségeit és tartják fenn az egyenlőtlenséget a munkaerőpiacon. Utána a közfoglalkoztatás interjúpartnerek által kedvezőnek ítélt munkafeltételeit 
(beosztás, elhelyezkedés és szabadság) vitatom meg. Végül bemutatom, hogy a közmunka hogyan elégíti ki a nőiesnek gondolt közösségi és emocionális szükségleteket.

\section{Nemi szerepek: a gondoskodó nő}

A nők munkalehetőségeit erősen formálják és olyakor limitálják a gondoskodási feladataik. A strukturális egyenlőtlenségek a munkaerőpiacon fenntartják a nemek közötti egyenlőtlenséget, és a gondoskodási feladattal rendelkező nőket büntetik. A közfoglalkoztatás ezeket az egyenlőtlenségeket betonozza be a munkaerőpiacon, mert lehetőséget ad arra, hogy a nők változatlanul egyedül viseljék a munka és az otthoni feladatok kettős terhét.

Cili közterület-fenntartással foglalkozó roma közmunkás, aki gondoskodási feladataira esti múszakként gondol. A munkaideje 3 óráig tart, és mivel korán haza tud menni, van ideje, hogy otthon elvégezze a házimunkát, és három kisgyermekével foglalkozzon. Mióta megszülettek a gyermekei, lehetetlennek tartja, hogy 12 vagy 16 órában dolgozzon. Cili így írja le egy átlagos napját:

„7-töl 3-ig van a munkaidő, és aztán hazamegyek, és max. egy-két óra hossza alatt minden megvan [fözés, takarítás] [...] majd biciklire ülök, és elmegyek a gyerekekért az óvodába, és jön az esti müszak: a fürdetés, enni adni nekik, és utána megint pakoljak öszsze... Nincs megállás este 9-ig/10-ig... Szóval a 12/16 óra [fizetett munka] sok lenne a gyerekek mellett, mert akkor is ugyanúgy kell mosni, fözni, takarítani."

Amikor a nők az otthoni feladataikról számoltak be, a férjük ritkán került szóba. A férfiak hiánya a gondoskodási, illetve otthoni feladatok mellőzésére utal. Ugyanakkor az is feltűnt, hogy a női résztvevők nem várnak el segítséget a férfiaktól. Noha voltak olyan családok, ahol a férfiak hét közben egy másik városban dolgoztak, és csak hétvégén jöttek haza, a nők nemcsak úgy érezték, hogy a gondoskodási feladatok és a házimunka az ő kötelességük, hanem hogy nekik ezeket természetes csinálniuk. Cilitől megkérdeztem, hogy a tinédzser fia segít-e neki a házimunkában, mire azt válaszolta: „Ö egy fiú, nem csinál ilyeneket. Hogy kiteregesse a mosást... á, nem. Nem neki való.” Ez a beszélgetésrészlet azt tükrözi, hogy a nők természetellenesnek tartják, hogy a férfiak részt vegyenek a házimunkában. Cilihez hasonlóan Linda véleményét is jelentősen formálták a nemi szerepek. Linda azt mondta, hogy amikor a gyerekeik betegek, az anyjukra van szükségük. Az apjuk nem tudna róluk elég jól gondoskodni. Ezek alapján elmondható, hogy a nemi szerepek befolyásolják az otthoni feladatok felosztását, ami hatással van a nők munkavállalására. A férfiakra a családfenntartó szerep, míg a nőkre a háztartásbeli szerep illik (Williams 2010: 78). Az otthoni munka elvégzésének érdekében a nők közmunkát vállalnak. Ez a stratégia nemcsak erősíti az ideális munkavállaló normáját és annak társadalmi nemek által meghatározott jellegét, de hozzájárul a férfiak hosszú munkaidejéhez is. A közfoglalkoztatás tehát egy újfajta rózsaszíngalléros munka, amely a magánélet és a mun- 
ka összeegyeztetésével kapcsolatos strukturális problémákat érintetlenül hagyja, és helyette egyéni megoldásokra ösztönöz.

A tradicionális nemi szerepek az ötvenes éveikben járó közmunkások attitűdjében is tükröződtek. Ezeknek a nőknek a gyerekei már felnőttek, és sok esetben saját családot alapítottak. Márti roma származású, a lányával és az unokájával él együtt. Beszélgetésünk alatt egy karitatív szervezet konyhájában sütött, ahol közmunkásként dolgozik. Többször is megemlítette, hogy ötre feltétlenül haza kell érnie, hogy ő vigyázzon az unokájára:

Márti: „A lányomnak is besegítek, mert ő is elvált. Most megyek haza 5 körül, ha minden igaz, és felváltom, mert ő megy dolgozni délután, az esti órákban."

Én: „Tehát ő két müszakban dolgozik?”

Márti: „Igen, és ezt azért tudja megcsinálni, mert én besegítek.”

Tehát a nők gondoskodási feladatai nem feltétlenül tűnnek el, miután a gyerekeik felnőnek. Az interjúpartnerek szerint a közfoglalkoztatás lehetőséget biztosít arra, hogy „leváltsák” családtagjukat, és helyettük vigyázzanak a gyerekekre. Ezáltal a program hozzájárul ahhoz, hogy egy gondoskodási feladattal rendelkező családtag egy olyan állást vállaljon el, amelyet a munkaidő miatt amúgy nem tudna. Márti azt is megemlítette, hogy mivel ő nem dolgozik a hétvégéken, a lánya egy közeli gyrososnál tud dolgozni, amíg Márti vigyáz a gyerekre. Tehát a családtagok fontos szerepet játszanak a munka és a magánélet konfliktusának feloldásában (GuerreiroPereira 2007: 193). A fent említett példában a gondoskodási feladatok megosztására egy anyuka és felnőtt lánya között kerül sor. Ez a fajta megegyezés kimondottan fontos az olyan családokban, ahol a férfi családfenntartó hiányzik, mert segít csökkenteni a fizetett munka, a gyereknevelés és a házimunka összehangolásának terhét (Utrata 2011: 617). Tehát az egyéni narrációk arra utalnak, hogy a közfoglalkoztatás egy stratégiát biztosít a magánélet és a munka összeegyeztetésére nemcsak a nagymamák számára, hanem azoknak a nőknek is, akik az ő segítségükre támaszkodnak.

Amikor a résztvevőket arról kérdeztem, hogy keresnek-e új munkát, a nők nagy részétől azt a választ kaptam, hogy most nem, de ha a gyerekek nagyobbak lesznek, akkor mindenképp szeretnének. Andi elmondta, hogy a jelenlegi munkája megfelelő a kislánya miatt, és nem tervez új munkahelyet keresni, amíg lánya nem tud egyedül iskolába járni. Tehát a nők a magánélet és a munka konfliktusa miatt tudatosan elhalasztják a munkahelykeresést, és így a közmunka egy stratégiai eszközzé válik, amíg gyermekük kicsi. A közfoglalkoztatás - csakúgy, mint más elnőiesedett munkák - fenntartja a strukturális problémákat és a munkaerőpiaci diszkriminációt. Az alacsony végzettséggel és gondoskodási feladatokkal rendelkező nők számára azonban olyan kevés a lehetőség az elsődleges munkaerőpiacion a munka és a magánélet konfliktusának feloldására, hogy a közfoglalkoztatás mint ideiglenes megoldás fel- 
értékelődik. Azt, hogy miért értékelődik fel a közfoglalkoztatás a résztvevők számára, mik azok a munkafeltételek, amelyek vonzóbbá teszik, a következő alfejezetben tárgyalom.

\section{Kedvező munkaidő és beosztás, lokális foglalkoztatás}

Mint azt az előző alfejezetben is kifejtettem, a családi és reprodukciós feladatok erősen korlátozták a résztvevők munkalehetőségeit. Már a kutatás legelején kiderült, hogy csaknem lehetetlen interjúkat készíteni közmunkásokkal a munkaidőn kívül, mivel a munkaidő lejárta után szinte mindenkinek vannak tervei, amelyek családhoz, gyerekekhez kötődnek. A munkaidő alatti interjúkat részben a kapcsolatom a munkafelügyelőkkel, részben pedig a nem profitorientált szektorban lévő lazább munkatempó segítette elő. Az egyik munkafelügyelő, Anna egy olyan karitatív szervezetnél dolgozik szociális munkásként, ahová jelenleg öt roma női közmunkást közvetítettek ki. Elmondása szerint a náluk dolgozóknak a közfoglalkoztatás belépést biztosít a munka világába a gyermekvállalás után. Anna észrevette, hogy az utóbbi három évben sokkal több női közmunkás van, mint férfi, és szerinte ez a változás a munkaidőnek tudható be. Cili, aki közterület-fenntartással foglalkozik, éppen a munkaidő miatt tartja vonzónak a közmunkát. Cili egy 35 éves roma nő. Három gyereke van, közülük kettő óvodás. A többműszakos beosztás problémáját így írja le:

„Van nagyon sok takaritásos munka. Csak az a problémám vele, hogy akkor el tudnám hordani a lányokat oviba, csak ott [munkában] délután 2-tôl 10-ig kéne, hogy legyek, és akkor megint egy másik pont, hogy most akkor ki hozza haza őket."

Cilihez hasonlóan Andinak is problémát jelentett a munkája mellett a gyermekeit iskolába vinni, de ő azt is megemlítette, hogy nincs, akitől segítséget kérhetne, mert a nagyszülők másik városban laknak. Andi egy 35 éves, négygyerekes roma nő, aki a közmunkát egy ideiglenes megoldásként fogja fel, amíg a gyerekei kicsik és nem elég önállóak. A közfoglalkoztatás előtt egy szendvicscsomagoló üzemben dolgozott. Mikor megkérdeztem, miért hagyta ott az előző munkahelyét, akkor egyértelműen a családi kötelességeire hivatkozott: „Hát, kislány végett [hagytam ott a munkám], mert nem tudtam megoldani úgy az iskolát. Hordani ôt. Este 9-kor fejeztük be a munkát, a nagyszülők nem laknak itt."

A fenti beszámolókból egyértelműen kiderül, hogy a női résztvevők egyedül gondoskodnak gyermekeikről, ami jelentősen korlátozza a munkalehetőségeiket, hiszen nincs, aki segíteni tudna nekik, ha ők nem tudják ellátni a feladatukat. Vagyis támogatói hálózat hiányában (Guerreiro - Pereira 2007: 193) más megoldás után kell nézniük a munka és a magánélet konfliktusának megoldására. Williams szerint a kiszámíthatatlan munkaidő problémát jelent azoknak a nőknek, akiknek gondoskodniuk kell a gyerekek napközi felügyeletének megoldásáról (2000: 80, 2010: 46). Tehát a munkaidőnek fontos szerepe van a nők különböző pozíciókból való kizárásá- 
ban vagy éppen a más pozíciókba történő bevonásában. A közfoglalkoztatás megadja ezt a lehetőséget, ugyanakkor megerôsíti azt a hozzáállást miszerint a gyermekekről való gondoskodás a nők feladata. A közmunka nem kérdőjelezi meg az elsődleges munkaerőpiacot meghatározó rugalmatlan munkaidőt, ami bizonytalanabb munkákba kényszeríti a nőket.

Voltak olyan esetek is, amikor maguk a közmunkások tudtak pluszmunkát vállalni kiszámítható munkaidejüknek köszönhetően. Anna több olyan férfi közmunkásról tudott, akik gyakran ad hoc munkákat végeztek munkaidejük lejárta után. Ez az extra bevételi forrás fontosnak bizonyult, hiszen a közmunkások bére igen alacsony.

László egy középkorú férfi, aki egy Komárom-Esztergom megyei városban felügyeli a közterület-fenntartással foglalkozó közmunkásokat. Elmondása szerint a motiváltabb, illetve jó egészségi állapottal rendelkező férfiak gyakran jártak magánemberekhez, hogy segítsenek a metszésben, fünyírásban vagy akár ültetésben egy kis extra pénzért. Mivel a férfiakat nem várta otthon a házimunka, képesek voltak a munkaidőn kívül is elvállalni különböző munkát. Ez viszont a nők privát szférában való láthatatlan támogatásának volt köszönhető (Acker 1990; Kelly et al. 2010: 294).

Az a megállapítás, hogy férfiak nem vesznek részt a házimunkában, illusztrálja a rájuk nehezedő nyomást, hogy megfeleljenek a családfenntartó szerepnek, illetve hogy képesek legyenek támogatni családjukat akár egy olyan munkával is, amely nemcsak bizonytalan hosszúságú, de alacsony bérezésű is.

Nemcsak a férfiak, hanem néhány nő is beszámolt arról, hogy alkalmi munkákat vállalt. Zsuzsi egy egyedülálló anyuka a negyvenes éveiben. 2010 óta dolgozik portásként a közfoglalkoztatási rendszerben. Az interjúnk alatt Zsuzsi szintén kiemelte, hogy állása a munkaidő miatt volt kedvező. Ugyanakkor hangsúlyozta, hogy a fizetés itt nagyon kevés. Előzőleg egy élelmiszerboltban dolgozott, ahonnan azért ment el, mert a munkáltatója nem akarta rendesen bejelenteni. Az előző munkahelyén gyakran dolgozott a hétvégéken is, de itt nem kell, és így pluszmunkát vállal ilyenkor, hogy kiegészítse a bérét. Ez különböző kerti munkákat jelent, amelyeket azóta csinál, amióta a lánya nagyobb. Zsuzsi szerencsésnek tartja magát, mert a volt férje fizeti a gyermektartásdíjat, nincsen kölcsöne, és egy kisebb lakásban lakik, ahol alacsony a rezsi. Így elmondása szerint ki tud jönni a pénzéből. A tömegközlekedés problémát jelent számára, mivel sokszor pánikrohamokkal küzd. A betegsége miatt maradt a jelenlegi állásában, miután a lánya idősebb lett. Tehát Zsuzsi opcióit először a családi kötelessége, majd az egészsége korlátozta.

Több nő is beszámolt arról, hogy nemcsak a pluszmunka jelentett extra pénzt, hanem a családi adókedvezmény is, amelyhez nem jutnának hozzá, ha feketén dolgoznának. Az adókedvezmény gyermekenként 10000 forint visszatérítést jelent, és maximum három gyermek után lehet igényelni. Ennek köszönhetően a három 18 év alatti gyermeket nevelő közfoglalkoztatott 60 százalékkal többet kereshet, mint az, akiknek nincs kiskorú gyermeke. Az adókedvezmény valamennyire enyhíti azokat a nehézségeket, amelyeket a család eltartásához túl alacsony bérezés okoz. 
A kedvező munkaidőn kívül az interjúpartnerek sokszor abban látták a közfoglalkoztatás előnyét, hogy a munkavégzés helyszíne közel van az iskolához. A munkahely, az iskola és az otthon közötti utazás megtervezése gyakran a nőkre hárul, hiszen ők viszik vagy veszik fel a gyerekeket. Az utazás logisztikai problémája sokszor felmondáshoz vezet (Perrons et al. 2007: 140).

Cili elmondta, hogy fontos, hogy helyben legyen munkalehetőség. Ő azért jelentkezett közmunkára, mert így a munkahelye közel van a lakhelyéhez és a gyerekei óvodájához. Cili a közmunka előtt egy csirkegyárban dolgozott. Reggel 6-kor busszal felvették és elvitték egy közeli városba, ahol a munkahelye volt. A korai kezdés problémásnak bizonyult, amikor a gyerekei elkezdtek óvodába járni. Mivel a gyerekeket nem tudta másra bízni, felmondott a munkahelyén, és a következő hónapban már közfoglalkoztatottként dolgozott.

Linda, egy 31 éves roma nő, kulturális közfoglalkoztatottként dolgozott. Ő volt az egyetlen interjúpartnerem, aki az interjú idejében már elhelyezkedett a munkaerőpiacon. Közfoglalkoztatottként munkáját a gyerekekről való gondoskodás tette ki. A munkahelye gyermekei bölcsődéje és óvodája mellett helyezkedett el, amit nagyon kedvezőnek talált.

$\mathrm{Az}$ interjúkon kívül a terepmunka, illetve a résztvevők megfigyelése is alátámasztotta a helyben lévő munkalehetőség fontosságát. A kutatás során részt vettem egy szünidei gyermekétkeztetésben, mert abba a karitatív szervezetbe szállították az ételeket az iskolaszünetben, ahol az interjúpartnerek egy része dolgozott. A meleg étel felvételére érkező anyukák közül többen kérték, hogy szóljanak, ha van felvétel a szervezetnél, hiszen olyan jó itt dolgozni, mert közel van a lakóhelyükhöz.

A fenti példák illusztrálják, hogy a 8-tól 4-ig tartó munkaidőnek köszönhetően a nőknek van idejük a fizetetlen munka elvégzésére: elvinni, illetve felvenni a gyerekeket az iskolából, vagy éppen befejezni otthon a házimunkát. Tehát annak ellenére, hogy a közfoglalkoztatási rendszer lehetőséget nyújt arra, hogy a nők részesei legyenek a munkaerőpiacnak, azt is biztosítja, hogy a házimunka továbbra is az ő feladatuk maradjon, otthon a második műszak (Hochschild - Machung 1989) várja őket. Így az alacsony végzettséggel rendelkező nők számára éppen úgy múködik a közfoglalkoztatás, mint a rózsaszíngalléros (pink-collar) munkák, amelyek hozzájárulnak a nemi egyenlőtlenségek fenntartásához. A munkaidő mellett sokan kiemelték a szabadság lehetőségét, a következő alfejezet ezt vitatja meg.

\section{A szabadság lehetősége: „Ha a gyerek beteg, az anyjának mellette a helye”}

A kiszámítható munkaidő mellett a résztvevők kiemelték a formális foglalkoztatás további előnyeit is, mint például a betegszabadság vagy a gyed. Linda nem tudott gyesről visszatérni az előző munkahelyére, mert felvettek helyette valaki mást. Bár sikerült egy új állást találnia, a munkáltatója nem tolerálta családi kötelességeit, és rövid időn belül elbocsátotta. Ezután vált kulturális közfoglalkoztatottá, ahonnan fél év elteltével gyedre ment. Hat hónappal második fia születése után, amikor a 
gyerek elkezdett bölcsődébe járni, probléma nélkül visszatért munkahelyére. Linda azt tapasztalta, hogy a közfoglalkoztatási rendszer toleránsabb és megértőbb a magánéleti gondokkal szemben, mint a versenyszféra. Amíg az ideális munkavállaló normája meghatározza a munkalehetőségeket a versenyszférában, addig az állami szektorban - ahová a közfoglalkoztatás is tartozik - az interjúpartnerek azt tapasztalták, hogy rugalmasabb munkakörülmények vannak, és a nők gyerekvállalás után is vissza tudnak térni a munkahelyükre. A munkáltatók, akik közmunkásokat alkalmaznak, sokszor engedékenyebbek, ami a rendszer munkaszocializációs funkciójával magyarázható. Némely esetben a munkáltató azt várja el mindössze, hogy rendszeresen, a munka ideje szerint járjon a munkavállaló dolgozni (Gerő - Vigvári 2019: 16). Ezáltal a közfoglalkoztatási rendszer hozzájárul a munkaerőpiac szegmentálásához, és fenntartja az elsődleges munkaerőpiac strukturális problémáit.

Hajni egy 31 éves roma nő, aki az interjú idején éppen babát várt. Lindával együtt dolgozik egy karitatív szervezetben, ahol általános iskolásoknak segít a leckeírásban. Ezt megelőzően rakodómunkásként dolgozott. Akkor nem volt bejelentve, így nagyon örül, hogy közmunkásként el tud majd menni gyedre, és magasabb kompenzációt kap, mint az általánosan elérhető gyermekgondozást segítő ellátás (gyes). A főnökével már megbeszélte, hogy amint bölcsődébe tudja vinni a gyerekét, vissza fog jönni dolgozni. Linda elmondta, hogy semmiképp sem akar kiesni a munkaerőpiacról, és biztosan vissza fog térni, amint tud. Tehát némely interjúpartner úgy érzékeli, hogy könnyebben tud visszatérni a közfoglalkoztatási programba a szülés után, mint a versenyszférába.

Anna a fizetett szabadság opcióját is kiemelte, amely szerinte különösen nagy segítséget nyújt a közfoglalkoztatottaknak. Több résztvevőnek nem volt lehetősége vagy nem tudott kivenni szabadságot, illetve táppénzre menni előző állásában. Linda ezt személyesen is tapasztalta, amikor a munkahelyéről a kisfia betegsége miatt küldték el. Correll és szerzőtársai szerint a munkahelyi hiányzást a munkáltató sok esetben az elkötelezettség hiányának ítéli meg. Ez az anyák esetében az úgynevezett anyasági büntetéshez (motherhood penalty) vezet, amely szerint az anyák kevésbé elkötelezett és kompetens munkaerőnek számítanak (Correll et al. 2007). Linda zaklatottan mesélt a tapasztalatairól, és emelt hangon fejezte ki frusztrációját az anyasági büntetéssel kapcsolatban.

„Azt nem értem, hogy őnekik [munkáltató] nem volt gyerekük soha? Mert ez nagyon nem szép dolog... meg nyilván nem találod ki, hogy a gyereked beteg. Ha beteg a gyerek, az anyjának mellette van a helye, nem fog ott maradni egy idegennel... A férjemmel nem lennének el konkrétan."

A fenti idézet rávilágít a nemi szerepek mentén meghatározott családi kötelességek és a munka konfliktusára. Linda, mint anyuka, természetesnek érezte, hogy beteg gyerekét ápolja. Erre azonban nem volt lehetősége a munkáltató rugalmatlansága 
miatt. Mivel a neoliberális intézkedések meggyengítették a munkavállalók védelmét szolgáló törvényeket, valamint az ideális munkavállaló normáját is fenntartják, ezáltal a család és a munka konfliktusa gyakran munkahelyük elvesztésével fenyegeti a nőket (Williams 2010: 42). A nők sokszor azért nem használják a rendelkezésükre álló rugalmasabb munkaidőt, mert vagy nem engedhetik meg maguknak, hogy kevesebb időt töltsenek munkában és kevesebbet keressenek, vagy félnek, hogy emiatt kirúgják őket (Hochschild 1997: 24). Közmunka előtt bejelentett állással rendelkező résztvevők gyakran mondták, hogy elviekben lett volna lehetőségük táppénzre menni vagy szabadságot kivenni, de szinte sose használták ki ezt a lehetőséget. Linda azt tapasztalta, hogy pontosan a fenti okok miatt az anyukák sokszor betegen viszik be a gyereküket az óvodába vagy bölcsődébe, és a saját gyerekei minden második héten betegek emiatt. Linda szerint „nem azért adják az anyukák be [a bölcsődébe a gyereket], mert unatkoznak, hanem mert nem tartják meg a helyüket, vagy kell a pénz, és inkább visszamennek".

Összeségében a közfoglalkoztatás vonzó az alacsony végzettségű, gondoskodási feladatokkal rendelkező nők számára, hiszen biztosítja a formális munka előnyeit, mint például a gyed vagy a szabadság. Jelentősen hozzájárul azonban a munkaerőpiac szegmentációjához, a nők kizsákmányolásához, és megerősíti a tradicionális nemi szerepeket.

\section{A közfoglalkoztatás emocionális és szociális előnyei}

Az előző alfejezetek bemutatták a közfoglalkoztatás szerepét a család és a magánélet összeegyeztetésében. A résztvevők a közfoglalkoztatás egy másfajta előnyét is sokszor említették, amely a munka jelentéséhez, illetve ahhoz kötődik, amit a munkájuk által érnek el az emberek (Wrzesniewski - Dutton 2001: 180). A résztvevők szerint a közmunka nemcsak a megélhetésben segít, de egyfajta kiteljesedést és elégedettséget is biztosít a dolgozók számára. Így a munka egy olyan hely, ahol elismerik az ember képességeit, és ahol egy közösség részei lehetnek, kapcsolatokat alakíthatnak ki. A következő alfejezetek a munka emocionális és szociális értékeire reflektálnak.

\subsection{Emocionális értékek}

A beszélgetések során a női résztvevők sok esetben kiemeltek egy bizonyos feladatot, amelyet élvezettel csinálnak, és amelyben örömet lelnek. Tehát a munkájuk nemcsak egy eszköz volt a pénzszerzésre, hanem hozzájárult egyfajta elégedettséghez is (Rosso et al. 2010: 98). Ez a megállapítás inkább azokra a közfoglalkoztatottakra volt igaz, akik zárt térben dolgoztak, tehát nem közterület-fenntartási munkakörben voltak alkalmazva. Anna szerint a legnagyobb előnye annak, hogy valaki egy olyan karitatív szervezetnél van elhelyezve, mint az övék, hogy van lehetőség különböző munkakörök kipróbálására. A zárt térben dolgozó közfoglalkoztatottak között kisebb volt a fluktuáció. Két nő, akivel Komárom-Esztergom megyében be- 
széltem, már a közmunkaprogram 2011-es átszervezése előtt is közfoglalkoztatottként dolgozott. Határozott időre szóló szerződésüket folyamatosan meghosszabbították. Ezek az esetek példák a közfoglalkoztatási programba való beragadás veszélyére, illetve annak kizsákmányoló jellegére.

A szabadban dolgozó résztvevők pályafutását gyakran jellemezték rövidebb és hosszabb megszakítások, illetve rotáció. Voltak esetek, amikor a közfoglalkoztatottak otthagyták a munkájukat pár hónapra, de volt olyan is, amikor nem hosszabbították meg a szerződésüket, és munka nélkül maradtak. Tehát a közfoglalkoztatás egy bizonytalan munkaviszonyt jelent, amely nem csökkenti a kiszolgáltatottságot vagy a foglalkoztatási bizonytalanságot. A megszakításokkal teli munkaviszony nemcsak azt befolyásolta, hogy a résztvevők hogyan viszonyulnak a munkához, hanem azt is meghatározta, hogy milyen kapcsolatokat voltak képesek kialakítani. Azok, akik zárt térben dolgoztak, gyakran egy csapat tagjai voltak, így ugyanazokkal az emberekkel dolgoztak együtt nap mint nap. Azok, akik a szabadban dolgoztak, sokszor egyedül vagy párban végezték munkájukat. A párosok tagjai viszont gyakran cserélődtek. Ezenfelül a közterület-fenntartással foglalkozók munkáját gyakrabban figyelték meg és ellenőrizték, míg a zárt térben dolgozók közül többen is egyéni munkát végeztek. Közterület-fenntartással foglalkozó résztvevők nem részesültek munkahelyi képzésben, és nem nagyon tudták megnevezni, hogy miket tanultak munkakörüknek köszönhetően. Tehát a magyar workfare-programból hiányzik az emberi erőforrás fejlesztése, ami egy fontos komponens lenne, hiszen javítja a résztvevők foglalkoztathatóságát.

Magdi néni egy 55 éves roma közmunkás, aki egy karitatív szervezet konyháján dolgozik, süteményeket és sós harapnivalókat készít. Termékeiket a helyi piacon adják el, illetve megrendelések alapján készítenek belőlük konferenciákra. Ezt megelőzően is közfoglalkoztatottként dolgozott, közterület-fenntartással foglalkozott nyolc hónapig, de az állam nem támogatta tovább a programot, amelyben részt vett, így megszűnt a munkaviszonya. Magdi néni nem szeretett az utcán söpörni, ezt a fajta munkát megalázónak tartotta, ami ellentétben állt azoknak a közfoglalkoztatottaknak a véleményével, akik az interjúk idején közterület-fenntartással foglalkoztak. A közmunka előtt Magdi néni egy pékségben dolgozott, de nem volt bejelentve. Amikor a sütésről beszélt, hangsúlyozta, hogy a finom íz nem elég, fontos, hogy a sütemény szépnek, gusztusosnak nézzen ki. Így nemcsak a vevők igényeit szolgálta ki, de a kreativitását is ki tudta fejezni (Wrzesniewski - Dutton 2001: 193). Magdi néni csupa mosoly volt, amikor a becsomagolt, kész termékeket, illetve a tőlük rendelhető dolgok hosszú listáját mutatta meg. Sok sütemény receptjét a nagymamájától tanulta. Már gyerekkorában is szeretett sütni, most is élvezettel süt, és örül, hogy újra ezzel foglalkozhat. Munkájáról így beszélt: „Itt is közmunkás vagyok, csak nem mindegy, hogy mit csinálok. Nem mindegy, hogy a szemetet túrom vagy süteményt csinálok. Ez sokkal finomabb... itt egész másképp érzem magam." 
Magdi néni sokszor mondta, hogy számára ez az ideális munkahely, és tökéletes lenne, ha többet fizetnének. Semmiképp se akar máshová menni, reméli, hogy valahogy itt tud maradni. Magdi néni nagyon túlhajszolva érezte magát a versenyszférában, amire végül ráment az egészsége. Rossz tapasztalatainak kontextusában ez a bizonytalan munkahely is jobbnak tünik.

Linda sok új dolgot tanult a gyerekekről a karitatív szervezetnél, ahol az interjú idején teljes állásban dolgozik. Munkatapasztalatának köszönhetően - és főnöke biztatására - jelentkezett óvodapedagógus képzésre. Linda elmondta, hogy gyerekkorában ügyvéd vagy tanár akart lenni, de végül a közmunka alatt szerzett tapasztalatai miatt döntött úgy, hogy pedagógiai pályára megy. Linda példája nemcsak hangsúlyozza a képzés fontosságát a workfare-politikában, de alátámasztja azt a megközelítést is, miszerint a munka lehetőséget nyújt az egyének fejlődésére és kiteljesedésére (Eichhorst et al. 2008: 6; Lips - Wiersma et al. 2016). Fontos megemlíteni azonban, hogy Linda helyzete egyedi volt az interjúpartnerek között. Ráadásul a közmunkaprogramtól nem kapott közvetlen támogatást, hogy elvégezzen egy olyan szakmát, amelyből munkaerőhiány van (EMMI 2014: 78).

Márti, aki a sütödében segít, kiemelte, hogy nemcsak örömet lel a munkájában, de hasznosnak is tartja. Csakúgy, mint Magdi néni, Márti is egészségügyi problémákkal küzd, ezért a munkatempója lassabb, és a versenyszférában levő hajtást nem bírja. Viszont itt, a sütödében ezzel nincs probléma, mert pihenhet, amikor akar. Márti esete szintén felhívja a figyelmet a korábban említett munkaerőpiaci rugalmatlanságra, amely korlátozza az alacsony végzettségú, illetve rossz egészségi állapotban lévő nők munkalehetőségeit. Márti kiemelte, hogy a sütődében a munkatársai is elismerik a munkáját. Ez egy kölcsönös szolidaritáshoz vezet a résztvevők között, amelyet a versenyszférában sokan nem tapasztaltak (Brun - Dugas 2008: 725).

„A bánásmód. Az iszonyatos. Nem tudom, hogy a börtönökben mi van, hála jó istennek, mert nem voltam még megbüntetve, de szerintem ugyanaz. Rohadt barbárok. Egy pici hatalmat kapnak, és akkor vágják ott az embereket, mint a répát. De még a munkás is. Még munkás is, és ez a baj."

Brun és Dugas (2008: 717) szerint az elismerés fontos része az érdemi munkának. Az interjúpartnerek gyakran büszkén mesélték, hogy mások elismerték a munkájukat, vagy megdicsérték őket. Cili elmondása szerint fontos, hogy rendben tartsák az utcákat, és nélkülük nagy lenne a szemét. Tehát a közfoglalkoztatottak munkája jól látható, és az emberek elismerik azt. Az úgynevezett piszkos munkák (dirty work) - mint például a takarítás - is jelentéssel bírnak, mert a közjót szolgálják (Lips Wiersma et al. 2016: 53). A közterület-fenntartási munkát mind a közfoglalkoztatottak, mind a helyi lakosok hasznosnak ítélik meg, mert egy tisztább környezetet biztosít. Habár a közjó szolgálata közvetlenül nem jelent meg az interjúkban, azt 
azonban kifejezték a résztvevők, hogy ha nem végeznék el a munkájukat, az problémát okozna a városnak és a lakosoknak.

Zsuzsi, aki portásként dolgozik, azt emelte ki, hogy munkája szakértelmet és hozzáértést tükröz. Vagyis a feladatai lehetőséget adnak arra, hogy kifejezze képességeit, és hozzájárul az önmegvalósításhoz (Lips - Wiersma et al. 2016). Wrzesniewski és Dutton (2001: 191) szerint az egyén munkakörén kívül eső feladatok elvégzése segít abban, hogy létfontosságúnak ítélje meg valaki a munkáját. Zsuzsi részletesen mesélt a feladatairól, elmondta, hogy nemcsak útba igazítja az embereket - amit egy átlagos portás csinál - hanem a telefont is ő kezeli, több jegyzőkönyvet vezet, és ő postázza a leveleket. Zsuzsi szerint a munkája szükséges ahhoz, hogy mások is rendesen tudják végezni a feladataikat. Ezt az egymásrautaltságot a séf és a kukta kapcsolatához hasonlította. Zsuzsi arra is felhívta a figyelmem, hogy nem mindenki tudja elvégezni ezt a munkát, például az előtte itt dolgozóval problémák voltak. Az is szóba került, hogy vannak munkatársak, akik lenézik Zsuzsit, mert ő közmunkás. Zsuzsi a munkatapasztalatának leírásakor hozzáértését és szakértelmét hangsúlyozta, ami egyfajta stratégia a stigma feldolgozására.

Magdi néni nemcsak a szakértelmét tudja kifejezni a sütéssel, de ez a munka egyfajta identitást is ad neki. Tehát a munkája segít az önmegvalósításban. Magdi néni szerint abban mutatkozik meg, hogy minőségi munkát végez, hogy több étterembe is hívták dolgozni. Hochschild szerint a fizetett munka vonzóbb, mint a házimunka, mert társadalmilag jobban értékelik, sokaknak kikapcsolódást biztosít, illetve bizonyítékot nyújt arra, hogy értenek valamihez. Mindeközben az otthon olyan ismétlődő feladatokkal van tele, amelyektől sokszor irtóznak az emberek. Vagyis felcserélődött az, amit az otthon, és az, amit a munka nyújt (Hochschild 1997: 26). Az interjúnk alatt Magdi nénit felhívták az unokája iskolájából. Magdi néni sóhajtozva mesélte el, hogy az unokája, akit ő nevel, összeveszett egy másik gyerekkel az iskolában. Már megint. Ebből a megfigyelésből, valamint abból, ahogy a házimunka monotonitásáról panaszkodott, világossá vált, hogy a családi élet fárasztó és megterhelő, míg a fizetett munka kikapcsolódást biztosít.

Az öröm és büszkeség, amelyet a fizetett munkájuk miatt éreztek a résztvevők, erős ellentétben állt azzal, ahogy a házimunkára gondoltak. A házimunka egy második múszak volt, a napi rutin része, véget nem érő, repetitív feladatok sokasága (Hochschild - Machung 1989). Semmifajta elismerés nem kapcsolódott a házimunkához, senki se dicsekedett azzal, hogy gyönyörú tisztaság van nála, vagy milyen jó ebédet főzött. Vagyis a fizetetlen munka nem volt olyan értékes, mint a fizetett. Nem számított igazi munkának, nem adott alkalmat az önmegvalósításra, míg a fizetett munka által kompetensnek és hasznosnak érezték magukat. Hajnival való beszélgetésem jól illusztrálja ezt a pontot.

Hajni, aki - mint korábban említettem - egy karitatív szervezetben dolgozik, azért szeretett volna a közmunkaprogramban részt venni, hogy ne otthon lustál- 
kodjon, hanem dolgozzon. Amikor azonban a napirendjéről beszéltünk, kiderült, hogy sok ház körüli munkát végez nap mint nap.

„Hazamegyek 4 órakor, nekiállok fözni, persze van egy szép, aranyos párocskám, aki után takarítani kell. Tehát rosszabb, mint egy kisgyerek... aztán ót is el kell látni. Aztán este már hullán esek be az ágyba."

Ezekre a feladatokra azonban nem mint munkára gondolt, hanem mint gondoskodási kötelességre. Az ő feladata a ház rendben tartása, és az, hogy kiszolgálja a párját. Tehát a tradicionális nemi szerepek jelentősen befolyásolják az otthoni munkamegosztást. A reproduktív munka értéktelennek nyilvánítása, valamint az a gondolat, hogy akik nem vesznek részt fizetett munkában, azok lusták, nemcsak a workfarepolitika üzenete, hanem jelen van különböző roma sztereotípiákban is. Williams szerint a faji hovatartozás befolyásolja a munkával és az anyasággal kapcsolatos elvárásokat. Kisebbséghez tartozó nőktől kevésbé elfogadható, hogy ne legyenek aktívak a munkaerőpiacon, amikor gyerekük van (Williams 2010: 93). Hajni úgy érezte, a közmunka lehetőséget adott, hogy a vele kapcsolatos elvárásoknak megfeleljen, és bebizonyítsa, hogy őt nem határozza meg ez a sztereotípia.

A narrációk alapján elmondható, hogy a résztvevők egyfajta limitált kiteljesedést, örömet és elégedettséget éreztek a közmunkában, ami hozzájárult identitásuk kialakításához. Mindez egy olyan kontextusban történik, ahol a női résztvevőknek annyira limitált opcióik vannak az elsődleges munkaerőpiacon, hogy a közfoglalkoztatás a maga kizsákmányoló jellegével is jobb opciónak tűnik, mint más formális, informális munkák a munkaerőpiacon. A közfoglalkoztatás azonban egy zsákutca, hiszen nem kínál méltó kompenzációt és előrelépést a munkájukat jól végző, de hátrányos helyzetben lévőknek.

\subsection{Szociális értékek}

Az emocionális értékek mellett többen kiemelték, hogy munkájuk által egy közösség részei lehetnek. A kapcsolatok kialakításában is fontos szerepet játszott, hogy a résztvevők közterület-fenntartással vagy zárt térben végezhető munkával foglalkoztak. A fizetett munka lehetőséget ad a társasági élet megélésére (Perrons et al. 2007: 145; Rosso et al. 2010: 92), de ezzel a lehetőséggel azok tudtak élni, akik egy csapatnak voltak a tagjai. Mint azt már korábban említettem, ez inkább a zárt térben végzett munkakörökben fordult elő. Még Zsuzsi is, aki portásként dolgozik, a csapat tagjának érezte magát az egymásrautaltság miatt. Ha valaki másokkal dolgozik együtt, sok esetben tapasztalja a csoporthoz való tartozás érzését, illetve a támogatást, amely értéket ad a munkájának (Lips - Wiersma et al. 2016: 537). A közterület-fenntartással foglalkozók körében magas volt a fluktuáció, és gyakori volt a munkaviszony szaggatottsága. Magdi néni, akinek mindkétfajta közmunkában van tapasztalata, elmondta, hogy a sütödében teljesen egymásra vannak utalva. Ezért ha 
beteg, aggódik, hogy a munkatársai boldogulnak-e nélküle. Szerinte a jelenlegi munkája csapatmunkára épül, míg a közterület-fenntartás egyéni munka.

„Ott nem volt az a szoros kötelék, mint itt. Mi egymásra nagyon rá vagyunk utalva. Ha én beteg is vagyok... ha én fel tudok kelni, lábra bírok állni, én nem hagyom az Ildit, mert ő bajba kerülne, ha én nem jövök be. A másik helyen, ha nem jött, nem jött. Attól még a szemetet ugyanúgy össze tudták gereblyézni."

Tehát Magdi néni szívesen jár be dolgozni a kollégái miatt, ők azok, akik motiválják. Márti - aki a sütödében dolgozott - is elmondta, hogy itt támogatják egymást az emberek. Ha valaki beteg, felhívják, és visznek neki, amit kér. Így a munkahely funkciója a közösségi értékek megosztása, illetve kapcsolatok kialakítása (Isaksen 2000: 99; Lips - Wiersma et al. 2016: 538).

A karitatív szervezetben dolgozó interjúpartnerek sok esetben családias környezetként írták le a munkahelyüket. Hangsúlyozták, hogy nem éri őket megkülönböztetés, ugyanaz vonatkozik rájuk, mint a nem közmunkásként dolgozókra. Lindát például felvették teljes állásban a szervezethez, így már nem közfoglalkoztatottként dolgozik ott. Elmondása szerint, noha tudják, kik a közmunkások, nem kezelik őket másképp. Jól kijönnek egymással, és szeretnek együtt dolgozni. Ez azt illusztrálja, hogy az emberi kapcsolatok fontosabbak annál, hogy kinek milyen a szerződése, vagy milyen beosztásban dolgozik. A beszélgetésekből az is kiderült, hogy a főnök nemcsak egyszerűen kiosztotta a különböző feladatokat, hanem felajánlott több feladatot is, amelyből választani lehetett. Ezáltal a résztvevők egy csapat tagjának érezték magukat, egyenlőnek a többiekkel.

Sokan lazábbnak írták le a mostani munkakörnyezetüket, mint az előzőt. Kisebb volt a feszültség, nyugodtabbak voltak, örültek, hogy a teljesítménybérrel járó stresszt elkerülték. A főnökkel való kapcsolatuk sokkal közelibb volt, mint az előző munkahelyükön. Magdi néni így írta le a főnökével való viszonyát: „Máshol nem találkoztam ilyen fönökkel. Nem rándul össze a gyomrom, amikor bejövök, jó ember, nem kiabál velünk, mindig szépen megkér, megdicsér bennünket." Elmondta azt is, hogy a pékségben, ahol dolgozott, úgy kezelték az embereket, mintha gépek lennének. Csak a termelés számított. Itt viszont emberként kezelik. Mivel a közfoglalkoztatásnak van egy munkaszocializációs feladata, vannak olyan esetek, amikor nem profittermelés miatt alkalmaznak valakit, ami nagyban befolyásolja a résztvevőkkel kapcsolatos elvárásokat (Gerő - Vigvári 2019). Így némely esetben a munkáltató rugalmasabb tud lenni.

Több résztvevőnek is megromlott az egészségi állapota, és többen hangsúlyozták, hogy a főnökük itt megértőbb és flexibilisebb. Márti és Mariska is elmondta, hogy ha fáradtak, megengedett, hogy leüljenek pihenni. Magdi néni erős kontrasztba állította a versenyszférában alkalmazott bánásmódot a mostanival. Régi főnöke többször is rákiabált, amikor leült, mert nem bírta a munkatempót, mondván „nem azért fizetlek, hogy itt ülj”. A mostani főnöke viszont arra biztatja, hogy figyeljen az 
egészségére. Magdi néni megmutatta, hogy egy vérnyomásmérőt biztosítottak neki, és főnöke megkérte, hogy használja, mielőtt beveszi a gyógyszerét. A főnökkel kialakított viszony befolyásolja az emberek hozzáállását a munkához (Brun - Dugas 2008: 724). Ezt tükrözi Magdi néni tapasztalata is:

„Jobb a közérzetem. Ha fáradt vagyok, akkor se vagyok fáradt. Hiába van sok [munka], én akkor is megcsinálom, mert ilyen emberekkel vagyok körülvéve... Egyszer jöttem ki, és a kapuban azt mondta a fönök, hogy de jó, hogy megtaláltam magát... Én csak néztem rá, de el is fordultam, mert elsírtam magam [elérzékenyülve, könnyes szemmel]."

Ezzel ellentétben Zsuzsi, aki egy önkormányzati iroda portáján dolgozik, sok esetben megkülönböztetve érezte magát, viszont panaszkodni nem mert, félt, hogy elveszíti a munkáját. A közfoglalkoztatási rendszer aránytalanul nagy hatalmat ad a munkáltatók kezébe, hiszen azok akár évekre is ki tudnak tiltani problémásnak ítélt résztvevőket a programból (Bördős 2014; Szikra 2014). Ezzel a közfoglalkoztatás fenntart egy alárendeltséget, és a kizsákmányolás eszközévé válik. Zsuzsi esete pontosan erre hívja fel a figyelmet. A résztvevők úgy érezték, hogy a munkájuk által egy közösség részesei lehetnek, de ettől még a közfoglalkoztatás bizonytalan jellege változatlan, az interjúalanyok nem tudták megválaszolni, hogy meddig maradhatnak jelenlegi pozíciójukban. Tehát a workfare-politika nem biztosít hosszú távú megoldást azokra a problémákra, amelyek miatt a résztvevők kiszorulnak az elsődleges munkaerőpiacról.

\section{Összegzés}

A magyar közfoglalkoztatási programok eredménytelennek bizonyultak az álláskeresők versenyszférába való visszaillesztésében. A közmunkaprogramban a résztvevők egy speciális jogviszony alá tartoznak, így nem vonatkozik rájuk a minimálbér. Annak ellenére, hogy a közfoglalkoztatás fix időtartamú, sokszor váratlanul félbeszakad. Mindezek miatt a közfoglalkoztatási rendszer egy bizonytalan formájú munkalehetőségnek tekinthető, és hozzájárul a munkaerőpiac dualizációjához. Egy olyan másodlagos piacot teremt, ahol rosszabbul fizető és bizonytalanabb munkák vannak, és ahol a nőket, illetve a kisebbségek tagjait gyakrabban alkalmazzák. A fent említett hátrányok ellenére a női közfoglalkoztatottak aránya folyamatosan növekedik az utóbbi években. Ez a megfigyelés különböző kérdéseket vet fel arról, hogy miért maradnak a nők gyakrabban a közmunkaprogramokban, mint a férfiak. Milyen előnyt nyújt a program a nők számára, amelyet a férfiak nem tartanak ugyanolyan fontosnak?

A kutatás alapján elmondható, hogy a női résztvevők a közfoglalkoztatást egy stratégiának tartják, amely segíti őket, hogy elérjék a munka és a magánélet „egyensúlyát”. A kiszámítható, 8-tól 4-ig tartó munkarendnek köszönhetően a nők el tud- 
ják vinni a gyereküket az óvodába vagy az iskolába, illetve el tudnak menni értük délután. A közfoglalkoztatás egy másik előnyét a fizetett szabadsághoz kötötték a résztvevők. A közmunkásoknak lehetőségük van szülési szabadságra menni, és utána vissza tudnak térni a munkahelyükre, ami az előző állásukban, a versenyszférában vagy az informális szektorban nem volt lehetséges. A betegszabadság és a fizetett szabadság segítséget jelentett a gyermekek betegsége esetén.

Mivel ezek a feltételek nem érhetőek el az alacsony végzettségű, gondoskodó feladatokkal rendelkező nők számára, ezért ők a közfoglalkoztatási rendszerbe sodródnak. Így a közfoglalkoztatási rendszer elősegíti a nők kizárását az elsődleges munkaerőpiacról, ahol az ideális munkavállaló erős ellentétben áll a tradicionális női nemi szereppel. $\mathrm{Az}$, hogy a résztvevők képesek voltak pozitív emocionális és szociális értékeket kötni a közmunkához, illetve egy pozitív képet kialakítani magukról, azt tükrözi, hogy a limitált opcióik közül mennyire felértékelődik számukra a közfoglalkoztatás.

A közfoglalkoztatási rendszer azonban nem nyújt hosszú távú megoldást, és nem csökkenti a résztvevők kiszolgáltatottságát, mert állami támogatás nélkül könnyen megszűnhet a munkájuk. A közmunkaprogram hozzájárul a nők kizárásához az elsődleges munkaerőpiacon, és ezáltal egy olyan másodlagos munkaerőpiac részesei lesznek, ahol alacsonyabb bérú, bizonytalanabb munkák dominálnak. A közfoglalkoztatás elnőiesedésével ezt a fajta munkát egy új típusú rózsaszíngalléros (pinkcollar) munkának tekinthetjük.

Ezenfelül a workfare-politika és -diskurzus leértékeli a fizetetlen munkát, és a munkaerőpiacon való részvételt várja el a nőktől. Ezt a gondolatot láthatóan internalizálták a résztvevők, hiszen értékesnek ítélték a fizetett munkát a fizetetlen munkával szemben. Egy ilyenfajta diskurzus megerősíti azokat a véleményeket, amelyek szerint a gyereknevelés és a háztartásvezetés kizárólag a nők feladata. Ezáltal a nemi szerepek változatlanul meghatározzák az otthoni munkamegosztást, és ez közvetlenül befolyásolja a nők munkalehetőségeit, hiszen eltérő pozíciókba irányítja a férfi és a női munkavállalókat. A közfoglalkoztatás a fizetett és fizetetlen munka kettős terhét rója a nőkre ahelyett, hogy a strukturális problémákat kezelné, és jobb munkakörülményeket teremtene a munkaerőpiacon. Az interjúkban ritkán említették a férfiakat, ami arra utalt, hogy ők nem részesei az otthoni, illetve a gondoskodási feladatok megoldásának. Tehát a közmunka nem kérdőjelezi meg a strukturális és a kapcsolati tényezőket, amelyek a munka és a gondoskodás döntésit befolyásolják (Crompton et al. 2007: 6), helyette inkább az egyéni felelősséget hangsúlyozza.

\footnotetext{
Abstract: The study assesses the reasons behind female public work employment and the perceived benefits and disadvantages of the program within Hungary. It addresses the difference between men's and women's experience and the reasons why women in a specific structural, relational and circumstantial context find public work attractive. The study is based on interviews I have conducted with 15 public workers and three managers in two different cities, one in Pest county and another one in Komárom-Esztergom county. The interviews demonstrate that female public work participants use their job as a strategic tool to achieve work-life balance in a time when the labor market is characterized by rigid work
} 
arrangements. However, this strategy allows women to continue to bear the double burden of paid and unpaid work instead of improving the conditions within the labor market for both sexes. In this way, public work becomes a tool that reinforces labor market discrimination and exploitation. With the increased ratio of women in public work, it becomes a new type of pink-collar employment that tolerates women's domestic duties just like most of the jobs where women are overrepresented. Despite the precarity that surrounds the job, women are able to derive emotional, social, and financial gains from it. This is because their options are so limited that public work is overappreciated. As the meaning of work for men is related to their provider role and to the identity they gain through their profession, for them public work is a means to material benefits and does not provide meaning or fulfillment.

Keywords: active labor market policy tools, workfare, gender, work, labor market inequalities

\section{Irodalom}

Acker, J. (1990): Hierarchies, Jobs, Bodies: A Theory of Gendered Organizations. Gender \& Society, 4(2): 139-158. https://doi.org/10.1177/089124390004002002

Acosta, P. A. - Olfindo, R. (2016): Workfare for Whom? A Critical Assessment of Workfare Programs in the Philippines. World Bank Social Protection Policy Note 12. Washington, D. C. : World Bank Group. http://documents.worldbank.org/curated/ en/174171484213399426/Workfare-for-whom-a-critical-assessment-ofworkfare-programs-in-the-Philippines (utolsó letöltés: 2020. 12. 21.)

Albert F. (2015): Public works in Hungary: an efficient labour market tool? European Social Policy Network Flash Report 2015/35. Brussels: European Commission.

Belügyminisztérium (2017): Beszámoló a 2016. évi közfoglalkoztatásról. Budapest: Belügyminisztérium. https://kozfoglalkoztatas.kormany.hu/download/4/8e/e1000/ Besz\%C3\%A1mol\%C3\%B3_2016_170713.pdf (utolsó letöltés: 2020. 12. 21.)

Belügyminisztérium (2019): Havi tájékoztató a közfoglalkoztatás alakulásáról. 2019. december. Budapest: Belügyminisztérium. https://kozfoglalkoztatas. kormany.hu/download/7/5f/82000/Havi\%20jelent\%C3\%A9s_2019_ dec_\%28port\%C3\%A11\%29.pdf (utolsó letöltés: 2020.12. 21.)

Besley, T. - Coate, S. (1992): Workfare versus Welfare: Incentive Arguments for Work Requirements in Poverty- Alleviation Programs. The American Economic Review, 82(1): 249-261. https://doi.org/10.22004/ag.econ.268349

Bördős K. (2014): A közfoglalkoztatás intézményi környezete - történeti áttekintés. In Fazekas K. - Varga J. (szerk.): Munkaeröpiaci tükör, 2014. Budapest: MTA KRTK KTI, 66-75.

Brumley, K. M. (2014): The Gendered Ideal Worker Narrative: Professional Women's and Men's Work experiences in the new economy at a Mexican Company. Gender \& Society, 28(6): 799-823. https://doi.org/10.1177/0891243214546935

Brun, J. - Dugas, N. (2008): An analysis of employee recognition: Perspectives on human resources practices. The International Journal of Human Resource Management, 19(4): 716-730. https://doi.org/10.1080/09585190801953723 
Busch I. - Lakatos J. (2017): A közfoglalkoztatásban dolgozó nők főbb jellemzői. In Fazekas K. - Szabó-Morvai Á. (szerk.): Munkaerőpiaci tükör, 2017. Budapest: MTA KRTK KTI, 194-196.

Cazes, S. - de Laiglesia, J. R. (2015): Temporary contracts and wage inequality. In Berg, J. (ed): Labour markets, institutions and inequality: Building just societies in the 21st century. Geneva: ILO, 147-184.

Correll, S. J. - Benard, S. - Paik, I. (2007): Getting a Job: Is There a Motherhood Penalty? American Journal of Sociology, 112(5): 1297-1339. https://doi.org/10.1086/511799

Crompton, R. - Lewis, S. - Lyonette, C. (2007): Introduction: The Unravelling of the 'Male Breadwinner' Model - and Some of its Consequences. In Crompton, R. Lewis, S. - Lyonette, C. (eds.): Women, men, work, and family in Europe. New York: Palgrave Macmillan, 1-16.

Cseres-Gergely Zs. - Molnár Gy. (2014): Munkapiaci helyzet a közfoglalkoztatásból való kilépés után. In Fazekas K. - Varga J. (szerk.): Munkaerőpiaci tükör, 2013. Budapest: MTA KRTK KTI, 143-153.

Eichhorst, W. - Kaufmann, O. - Konle-Seidl, R. (2008): Bringing the Jobless into Work? An Introduction to Activation Policies. In Eichhorst, W. - Kaufmann, O. - Konle-Seidl, R. (eds.): Bringing the Jobless into Work? Experiences with Activation Schemes in Europe and the US. Berlin: Springer, 1-16.

EMMI (2014): Nemzeti Társadalmi Felzárkózási Stratégia II.: tartósan rászorulók szegény családban élő gyermekek - Romák (2011-2020). http://www.kormany. hu/download/1/9c/20000/Magyar\%20NTFS\%20II\%20_2\%20mell\%20_ NTFS\%20II.pdf (utolsó letöltés: 2020. 12. 21.)

Gerő M. - Vigvári A. (2019): Közfoglalkoztatás, redisztribúció és helyi hatalom. Esély, 2019(2): 3-30.

Gill, K. - Greene, A. (2015): Theorizing patterns of labour market segregation and inequality. The Dynamics of Managing Diversity: A critical approach. London: Taylor and Francis, 57-84.

Guerreiro, M. - Pereira, I. (2007): Women's Occupational Patterns and Work-Family Arrangements: do National and Organisational Policies Matter? In Crompton, R. - Lewis, S. - Lyonette, C. (eds.): Women, men, work, and family in Europe. New York: Palgrave Macmillan, 190-209.

Hochschild, A. (1997): The Time Bind: Our homes are invaded by the time pressures of work, while the workplace has become a surrogate home. WorkingUSA, 1(2): 21-29. https://doi.org/10.1111/j.1743-4580.1997.tb00019.x

Hochschild, A. - Machung, A. (1989): The Second Shift. New York: Viking Penguin.

Isaksen, J. (2000): Constructing Meaning Despite the Drudgery of Repetitive Work. Journal of Humanistic Psychology, 40(3): 84-107. https://doi.org/10.1177/0022167800403008 Kálmán J. (2014): A közfoglalkoztatási programok háttere és nemzetközi tapasztalatai. In Fazekas K. - Varga J. (szerk.): Munkaerőpiaci tükör, 2014. Budapest: MTA KRTK KTI, 42-58. 
Keller J. - Kovács K. - Rácz K. - Swain, N. - Váradi M. (2016): Workfare Schemes as a Tool For Preventing the Further Impoverishment of the Rural Poor. Eastern European Countryside, 22(1): 5-26. https://doi.org/10.1515/eec-2016-0001

Kelly, E. L. - Ammons, S. K. - Chermack, K. - Moen, P. (2010): Gendered challenge, gendered response: Confronting the ideal worker norm in a white-collar organization. Gender \& Society, 24(3): 281-303. https://doi.org/10.1177/0891243210372073

Kildal, N. (2001): Workfare tendencies in Scandinavian welfare policies. Geneva: International Labor Office.

Kluve, J. - Schmidt, C. M. - van Ours, J. C. - Vandenbussche, H. (2002): Can Training and Employment Subsidies Combat European Unemployment? Economic Policy, 17(35): 409-448. https://doi.org/10.1111/1468-0327.00093

Közfoglalkoztatás (2017): A közfoglalkoztatás átalakítása. https://kozfoglalkoztatas. kormany.hu/a-kozfoglalkoztatas-atalakitasa (utolsó letöltés: 2020. 12. 21.)

Közfoglalkoztatás (2020): Közfoglalkoztatási Portál. http://kozfoglalkoztatas.kormany. hu (utolsó letöltés: 2020. 12. 21.)

KSH (2011): 2011. évi népszámlálás. http://www.ksh.hu/nepszamlalas/teruleti_ adatok (utolsó letöltés: 2020. 12. 21.)

Lewis, S. (1996): Rethinking employment: an organizational culture change framework. In Lewis, S. - Lewis, J. (eds.): The Work-Family Challenge: Rethinking Employment. London: Sage, 1-19.

Lewis, S. (2001): Restructuring workplace cultures: the ultimate work-family challenge? Women in Management Review, 16(1): 21- 29. https://doi.org/10.1108/09649420110380256

Lips-Wiersma, M. - Wright, S. - Dik, B. (2016): Meaningful work: differences among blue-, pink-, and white-collar occupations. Career Development International, 21(5): 534-551. https://doi.org/10.1108/CDI-04-2016-0052

Lødemel, I. - Trickey, H. (2001): 'An Offer You Can't Refuse': Workfare in International Perspective. Bristol: The Policy Press.

MacDonald, R. (2009): Precarious work: Risk, choice and poverty traps. In Furlong, A. (ed.): Handbook of Youth and Young Adulthood: New Perspectives and Agendas. London: Routledge, 167-175.

Mandel, H. - Semyonov, M. (2006): A Welfare State Paradox: State Interventions and Women's Employment Opportunities in 22 Countries. American Journal of Sociology, 111(6): 1910-1949. https://doi.org/10.1086/499912

Martin, J. P. - Grubb, D. (2001): What works and for whom: A review of OECD countries' experiences with active labour market policies. Swedish Economic Policy Review, 8: 9-56. https://doi.org/10.2139/ssrn.348621

Messing V. (2013): Active labor market policies with an impact potential on Roma employment in five countries of the EU. NEUJOBS Working paper No. 19.2. Budapest: NEUJOBS.

Perrons, D. - McDowell, L. - Fagan, C. - Ray, K. - Ward, K. (2007): Gender, Social Class and Work-Life Balance in the New Economy. In Crompton, R. - Lewis, S. - 
Lyonette, C. (eds.): Women, men, work, and family in Europe. New York: Palgrave Macmillan, 133-151.

Rosso, B. D. - Dekas, K. H. - Wrzesniewski, A. (2010): On the meaning of work: A theoretical integration and review. Research in Organizational Behavior, 30: 91127. https://doi.org/10.1016/j.riob.2010.09.001

Szikra D. (2014): Democracy and welfare in hard times: The social policy of the Orbán Government in Hungary between 2010 and 2014. Journal of European Social Policy, 24(5): 486-500. https://doi.org/10.1177/0958928714545446

Tardos K. (2015) Halmozódó diszkrimináció. Kirekesztés és integráció a munkaerőpiacon. Szeged: Belvedere.

Utrata, J. (2011): Youth Privilege: Doing Age and Gender in Russia's Single-Mother Families. Gender \& Society, 25(5): 616-641. https://doi.org/10.1177/0891243211421781

Wacquant, L. (2009): Punishing the Poor: The Neoliberal Government of Social Insecurity. Durham: Duke University Press.

Wall, K. (2007): Main Patterns in Attitudes to the Articulation Between Work and Family Life: a Cross-National Analysis. In Crompton, R. - Lewis, S. - Lyonette, C. (eds.): Women, men, work, and family in Europe. New York: Palgrave Macmillan, 86-115.

Williams, J. C. (2000): Unbending gender: why family and work conflict and what to do about it. New York: Oxford University Press.

Williams, J. C. (2010): Reshaping the work-family debate: why men and class matter. Cambridge: Harvard University Press.

Williams, C. L. - Muller, C. - Klansky, K. (2012): Gendered Organizations in the New Economy. Gender \& Society, 26(4): 549-573. https://doi.org/10.1177/0891243212445466 Wrzesniewski, A. - Dutton, J. E. (2001): Crafting a Job: Revisioning Employees as Active Crafters of Their Work. The Academy of Management Review, 26(2): 179201. https://doi.org/10.5465/amr.2001.4378011 